\title{
Kategorisasi Karakteristik Ruang Terbuka Hijau Publik untuk Menunjang Kenyamanan Kota Yogyakarta
}

\author{
Ayu Candra Kurniati ${ }^{1}$, dan Akhmad Zamroni ${ }^{1}$
}

${ }^{1}$ Institut Teknologi Nasional Yogyakarta; e-mail: ayu.candra@itny.ac.id

\begin{abstract}
ABSTRAK
Pentingnya ketersediaan RTH bukan hanya secara kualitatif namun juga kualitas bagi sebuah Kota diharapkan mampu untuk menunjang tingkat kenyamanan Kota. Kondisi lingkungan yang buruk dapat meningkatkan stres masyarakat karena terbatasnya ketersediaan ruang terbuka untuk berinteraksi sosial. Kenyamanan Kota Yogyakarta memiliki nilai terendah pada ketersediaan fasilitas ruang terbuka hijau. Terdapat beberapa RTHP di Kota Yogyakarta yang kurang ramah terhadap lansia, anak dan disabiltas karena kurangnya fasilitas dan kontur tanah lokasi RTHP yang dekat dengan sungai. Selain itu, terdapat 14 RTHP atau sebesar 29,79\% yang memiliki kualitas kenyamanan tertinggi/sangat nyaman, 26 RTHP atau sebesar 55,32\% yang memiliki kualitas kenyamanan sedang/nyaman dan 7 RTHP atau sebesar 14,89\% yang memiliki kualitas kurang nyaman di Kota Yogyakarta. Berangkat dari pemikiran-pemikiran tersebut tujuan dari penelitian ini adalah mengidentifikasi karakteristik RTHP dalam menunjang kenyamanan Kota Yogyakarta. Hasil perbedaan karakteristik RTHP akan diklasifikasikan berdasarkan tujuh variabel kenyamanan Kota, yaitu variabel sirkulasi, kebersihan, keamanan, keindahan, bentuk, kebisingan dan penerangan. Metode yang dipergunakan adalah analisis deskriptif kualitatif yang digambarkan dengan peta kategori RTHP masing-masing variabel. Kategori yang memiliki nilai kesamaan karakteristik dominan adalah kategori yang hanya terdiri dari dua-tiga kode kategori, seperti pada variabel keamanan, penerangan dan sirkulasi. Hal ini menunjukkan bahwa pada ketiga variabel tersebut pemerintah memiliki konsep yang matang dan pemahaman mengenai kenyamanan RTHP. Kategori yang memiliki variasi karakteristik yang cukup luas (banyak memiliki perbedaan karakteristik) yaitu pada variabel keindahan dengan 12 kode kategori. Selanjutnya, kategori prioritas untuk meningkatkan kenyamanan pada variabel sirkulasi adalah kategori A, variabel kebersihan adalah kategori G, variabel keamanan adalah kategori A, variabel keindahan adalah kategori D, variabel bentuk adalah kategori E, kebisingan adalah kategori D dan penerangan adalah kategori A. Untuk perencanaan dan pembangunan RTHP selanjutnya, diharapkan pemerintah memiliki standar dalam mengidentifikasi variabel kenyamanan, sehiggga baik pengunjung maupun masyarakat sekitar dapat lebih nyaman beraktivitas di RTHP yang juga dapat menunjang kenyamanan Kota Yogyakarta.
\end{abstract}

Kata kunci: Kenyamanan Kota, Kategori, Karakteristik, Ruang terbuka hijau publik, Kriteria

\begin{abstract}
The essential of public green open space (RTHP) availability is not only qualitative but also the quality of a City. Bad environmental conditions can increase people's stress due to the limited availability of open spaces (both green and non-green space) for social interaction, so that RTHP is expected to be able to support the amenities level of a City. There are several RTHPs in Yogyakarta City that are less friendly to the elderly, children and people with disabilities due to the lack of facilities and land contours where the RTHP is close to the river. Furthermore, there are 14 RTHP or 29,79\% which have the highest / very comfortable comfort quality, 26 RTHP or 55,32\% which have moderate / comfortable comfort quality and 7 RTHP or $14,89 \%$ which have less comfortable quality in Yogyakarta City. The purpose of this study was to identify the characteristics of RTHP in supporting the convenience of Yogyakarta City. The differences in the characteristics of RTHP were classified based on seven City amenities variables (circulation, cleanliness, security, beauty, shape, noise, and lighting). The method of this study is a qualitative descriptive analysis depicted by a map of each RTHP classification variable. The classification that has the same dominant characteristic value is a classification which only consists of two or three classification codes, such as the variables of safety, lighting, and circulation. This shows that for the three variables, the government already has a good concept and understanding of the amenities of RTHP. The classification that has a fairly wide distribution of characteristics (many have different characteristics) is the beauty variable with 12 classification codes. Furthermore, the priority category for increasing comfort in the circulation variable is category $A$, the hygiene variable is category $G$, the safety variable is category $A$, the estetic variable is category $D$, the shape variable is category E, noise is category D and lighting is category A. Eventually, planning and further development of RTHP, the Yogyakarta City government is expected to have standards in identifying amenities variables so that visitors and the surrounding community can be more comfortable doing activities in RTHP which also correlates with the increasing comfort of the City of Yogyakarta.
\end{abstract}

Keywords: Urban amenities, Classification, Characteristic, Green open space, Criteria

Citation: Kurniati, A.C., dan Zamroni, A. (2021). Kategorisasi Karakteristik Ruang Terbuka Hijau Publik untuk Menunjang Kenyamanan Kota Yogyakarta. Jurnal Ilmu Lingkungan, 19(1), 127-139, doi:10.14710/jil.19.1.127-139 


\section{Pendahuluan}

Ruang Terbuka Hijau (RTH) merupakan bagian dari Kota yang tidak terbangun, yang berfungsi sebagai penunjang tuntutan akan kenyamanan, peningkatan kualitas lingkungan dan pelestarian alam. Kenyamanan sangat dibutuhkan dalam menunjang semua kegiatan, termasuk kegiatan yang dilakukan masyarakat di wilayah Kota. Ketersediaan RTH yang mudah dijangkau, memberikan rasa aman dan semakin dilengkapi dengan berbagai fasilitas publik diharapkan membuat masyarakat menjadi semakin nyaman untuk beraktivitas di Kota Yogyakarta (Imansari \& Khadiyatna, 2015; Smith \& Poulus, 2020). RTH dalam lingkungan pembangunan secara global saat ini diperlukan demi menjaga keseimbangan kualitas lingkungan hidup suatu daerah khususnya di daerah perKotaan yang memiliki berbagai permasalahan berkaitan dengan masalah ruang yang sedemikian kompleks. RTH khususnya di wilayah perKotaan memiliki fungsi yang penting diantaranya terkait aspek ekologi, sosial budaya, dan estetika. Berkaitan dengan fungsi secara ekologi misalnya, ruang terbuka hijau berfungsi sebagai pengendali iklim yakni sebagai produsen oksigen, peredam kebisingan, dan juga berfungsi sebagai visual control / kontrol pandangan yaitu dengan menahan silau matahari atau pantulan sinar yang ditimbulkan (Imansari \& Khadiyatna, 2019).

Ruang Terbuka Hijau (RTH) memiliki posisi yang penting, namun pertambahan penduduk menggeser jumlah RTH yang memadai menjadi semakin sedikit, serta implikasi terhadap pengendalian ruang yang buruk menyebabkan konversi lahan dari lahan nonterbangun menjadi lahan terbangun yang semakin tinggi (Suharyadi, 2017). Luas RTH publik di Kota Yogyakarta pada 2014 mencapai 628,98 hektar dan untuk RTH privat mencapai 561,65 hektar. Khusus untuk RTH publik mengalami peningkatan cukup baik setelah pada 2010 luas lahannya hanya 557,90 atau 17,17 persen dari luas wilayah Kota Yogyakarta (Pusdi Gajahmada, 2015). Tahun 2018, luas RTH yang ada belum sesuai dengan target tata ruang, yaitu 30\% dari total luas Kota Yogyakarta. Luas RTH Hanya 6,09 $\mathrm{km} 2$, atau $18,76 \%$ dari total luas wilayah Kota Jogja $32,5 \mathrm{~km} 2$, yang terdiri atas RTH publik 5,83\% dan RTH privat 12,93 \% (Radar Jogja, 2018). Sedangkan pada tahun 2019 luasan total RTH di Kota Yogya pada tahun 2019 seluas 6.109.988 m2 atau sekitar 18,8\% dari total luas wilayah Kota Yogya yang seluas $32 \mathrm{~km} 2$ (Pribadi, 2020)

Pentingnya ketersediaan RTH bukan hanya secara kualitatif namun juga kualitas bagi sebuah Kota diharapkan mampu untuk menunjang tingkat kenyamanan Kota (Wirastri \& Pramudito, 2019). Menurut Sari (2018) mengatakan bahwa salah satu unsur pendukung kenyamanan Kota adalah dari ketersediaan RTH. Kondisi lingkungan yang buruk dapat meningkatkan stres masyarakat karena terbatasnya ketersediaan ruang terbuka (baik terbuka hijau maupun non hijau) untuk berinteraksi sosial (Syahadat \& Putra, 2017; Oktaviani \& Ariana, 2019; Braharsyah \& Surhayadi, 2018). Kondisi RTHP di Kota Yogyakarta belum dapat diakses oleh seluruh kelompok masyarakat, karena terdapat beberapa RTHP di Kota Yogyakarta yang kurang ramah terhadap lansia, anak dan disabiltas karena kurangnya fasilitas dan kontur tanah lokasi RTHP yang dekat dengan sungai (Rusqiyati 2019). Berdasarkan hasil penelitian yang peneliti lakukan, terdapat 14 Ruang Terbuka Hijau Publik (RTHP) atau sebesar 29,79\% yang memiliki kualitas kenyamanan tertinggi/sangat nyaman, 26 RTHP atau sebesar $55,32 \%$ yang memiliki kualitas kenyamanan sedang/nyaman dan 7 RTHP atau sebesar 14,89\% yang memiliki kualitas kurang nyaman di Kota Yogyakarta.

Berangkat dari pemikiran-pemikiran tersebut penelitian ini ingin mengidentifikasi bagaimana karakteristik kenyamanan RTH dalam menunjang kenyamanan Kota Yogyakarta, terlebih lagi dalam survey indeks kenyamanan Kota (liveable city index) menurut Ikatan Ahli Perencana (IAP) (2020) mengatakan bahwa fasilitas ruang terbuka hijau termasuk dalam lima aspek terendah di Kota Yogyakarta. Hasil penelitian dapat bermanfaat untuk memberikan gambaran karakteristik ruang terbuka hijau publik yang dibangun oleh pemerintah Kota Yogyakarta guna meningkatkan kenyamanan masyarakat dalam beraktivitas di Kota Yogyakarta.

\section{Metode Penelitian}

Tujuan dari penelitian ini adalah mengidentifikasi karakteristik ruang terbuka hijau publik yang tersebar di seluruh Kota Yogyakarta, yaitu di 47 titik RTHP. Pendekatan penelitian dan metode analisis yang dipergunakan adalah deskriptif kualitatif untuk menggambarkan karakteristik RTHP dengan teknik observasi sebagai metode pengambilan data. Penentuan titik populasi RTHP diperoleh dari data persebaran RTHP yang terdapat di Dinas Badan Perencanaan Daerah (Bappeda) dan google map serta street view. Berikut Tabel 1 dan peta (Gambar 1) persebaran RTHP di Kota Yogyakarta.

Variabel yang dipergunakan adalah variabel untuk menilai kenyamanan RTHP (Hakim, 2012) dimana kenyamanan ditentukan oleh beberapa unsur pembentuk dalam perancangan yakni sirkulasi, daya alam/iklim, kebisingan, aroma/bau-bauan, bentuk, keamanan, kebersihan, keindahan dan penerangan (Wirastri dan Pramudito, 2019). Definisi operasional dari masing-masing variabel dijelaskan pada Tabel 2. 


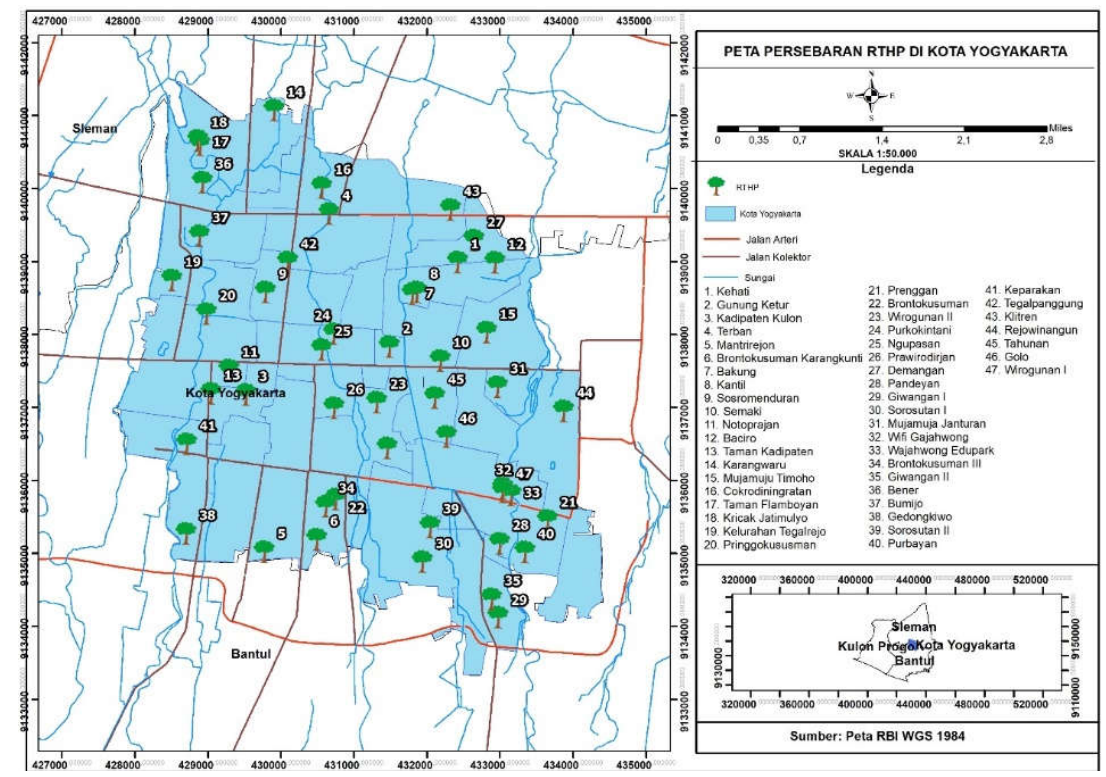

Gambar 1. Lokasi Persebaran RTHP di Kota Yogyakarta

Tabel 1. Persebaran RTHP di Kecamatan Kota Yogyakarta

\begin{tabular}{|c|c|c|}
\hline No & Kecamatan & RTHP \\
\hline 1 & Kecamatan Ngampilan & RTHP Notoprajan \\
\hline 2 & Kecamatan Gedongtengen & $\begin{array}{l}\text { RTHP Sosromenduran } \\
\text { RTHP Pringgokusuman }\end{array}$ \\
\hline 3 & Kecamatan Keraton & $\begin{array}{l}\text { - RTHP Kadipaten Kulon } \\
\text { - RTHP Kelurahan Kadipaten }\end{array}$ \\
\hline 4 & Kecamatan Kotagede & $\begin{array}{ll}\text { - } & \text { RTHP Prenggan } \\
\text { - } & \text { RTHP Rejowinangun Purbayan }\end{array}$ \\
\hline 5 & Kecamatan Megangsan & $\begin{array}{ll}\text { - } & \text { RTHP Keparakan } \\
\text { - } & \text { RTHP Brontokusuman } 1 \\
\text { - } & \text { RTHP Brontokusuman } 2 \\
\text { - } & \text { Wirogunan } 1 \\
\text { - } & \text { Wirogunan } 2 \text { (Surokarsan) }\end{array}$ \\
\hline 6 & Kecamatan Pakualaman & $\begin{array}{l}\text { - } \text { RTHP Gunungketur } \\
\text { - RTHP Purwokinanti }\end{array}$ \\
\hline 7 & Kecamatan Gondomanan & $\begin{array}{l}\text { - } \text { RTHP Ngupasan } \\
\text { - } \text { RTHP Prawirodirjan }\end{array}$ \\
\hline 8 & Kecamatan Mantrijeron & $\begin{array}{l}\text { - RTHP Mantrijeron } \\
\text { - RTHP Gedongkiwo }\end{array}$ \\
\hline 9 & Kecamatan Jetis & $\begin{array}{l}\text { - } \text { RTHP Cokrodiningratan } \\
\text { - RTHP Bumijo }\end{array}$ \\
\hline 10 & Kecamatan Gondokusuman & $\begin{array}{ll}\text { : } & \text { RTHP Taman Kehati } \\
\text { : } & \text { RTHP Klitren } \\
\text { : } & \text { RTHP Kelurahan Baciro } \\
\text { : } & \text { RTHP Kantil } \\
\text { : } & \text { RTHP Terbang } \\
\text { - } & \text { RTHP Demangan }\end{array}$ \\
\hline 11 & Kecamatan Umbulharjo & $\begin{array}{ll}\text { : } & \text { RTHP Pandeyan } \\
\text { : } & \text { RTHP Giwangan } 1 \\
\text { : } & \text { RTHP Goronangan } 2 \\
\text { : } & \text { RTHP Sorosutan } 1 \\
\text { : } & \text { RTHP Semaki } \\
\text { : } & \text { RTHP Mujamuju Janturan } \\
\text { : } & \text { RTHP Mujamuju Umbulharjo } \\
\text { : } & \text { RTHP Golo } \\
\text { - } & \text { RTHP Tahunan }\end{array}$ \\
\hline 12 & Kecamatan Tegalrejo & $\begin{array}{ll}\text { : } & \text { RTHP Tegalrejo } \\
\text { : } & \text { RTHP Kricak Taman Flamboyan } \\
\text { : } & \text { RTHP Bener } \\
\text { - } & \text { RTHP Karangwaru }\end{array}$ \\
\hline 13 & Kecamatan Danurejan & $\begin{array}{ll}\text { - } & \text { RTHP Tegalpanggung } \\
\text { - } & \text { RTHP Gajahwong Edupark } \\
\end{array}$ \\
\hline
\end{tabular}


Tabel 2. Definisi Operasional Variabel Penelitian

\begin{tabular}{ll}
\hline \hline \multicolumn{1}{c}{ Variabel } & \multicolumn{1}{c}{ Definisi Operasional } \\
\hline Sirkulasi & Berkaitan dengan aksesibilitas jalan menuju ruang terbuka hijau publik, jenis perkerasan jalan, dan lebar jalan \\
Kebersihan & Berkaitan dengan seberapa banyak fasilitas kebersihan yang mendukung kenyamanan dan kondisi kebersihan \\
diruang terbuka hijau publik tersebut & Bagaimana kondisi keamanan di RTHP, apakah terdapat fasilitas keamanan dan personil yang menjaga kemanan. \\
Keamanan & Baik di dalam RTHP maupun di luar RTHP \\
Keindahan & Berkaitan dengan unsur estetika yang ada diruang terbuka hijau publik tersebut, bagaimana memberikan suasana \\
& yang indah dipandang secara visual, memiliki point of interest, kerapian penataan tanaman dan fasilitas, serta \\
Bentuk & Berkaitan dengan penggunaan atau fungsi RTHP. Dengan asumsi bentuk yang cukup dan sesuai dapat menampung \\
& semua aktivitas masyarakat sekitar di RTHP. Menurut SNI kebutuhan luasan RTH PerKotaan dirancang dengan \\
& luasan 0,3-1 m²/jiwa \\
Kebisingan & RTHP dapat berfungsi sebagai barrier bunyi dari lingkungan sekitar apabila berada di dalam RTHP \\
Penerangan & Adanya penerangan buatan (lampu taman) yang berada di dalam maupun diluar RTHP. Selain itu dilihat dari cahaya \\
& matahari dapat secara langsung menyinari RTHP \\
\hline Sumber: Wirastri dan Pramudito, 2019; Imansari dan Khadiyatna, 2015
\end{tabular}

\section{Hasil dan Pembahasan}

Persebaran RTHP di 47 lokasi yang tersebar di 13 kecamatan Kota Yogyakarta memiliki karakteristik yang beranekaragam, sehingga menimbulkan adanya kategori/pengelompokan kesamaan karakteristik RTHP. Identifikasi terhadap pengelompokan karakteristik RTHP ini bertujuan untuk mempermudah dalam rencana peningkatan kualitas RTHP maupun rencana pembangunan RTHP yang saat ini menjadi perhatian masyarakat Yogyakarta.

Pendekatan yang dilakukan dalam upaya pengelompokan karakteristik adalah dengan menggunakan variabel kenyamanan Kota. Penggunaan kenyamanan Kota sebagai faktor penilai bertujuan agar penyediaan RTHP di Kota Yogyakarta bukan hanya sebagai paru-paru Kota namun juga dapat mendukung masyarakat dalam beraktivitas dan bertempat tinggal di Kota Yogyakarta. Keberadaan RTHP merupakan salah satu faktor pendukung Kota Yogyakarta menjadi Kota yang nyaman, meskipun juga dipengaruhi oleh faktor-faktor kenyamanan Kota yang lain. Tabel berikut merupakan hasil kategori karakteristik RTHP di Kota Yogyakarta menggunakan variabel kenyamanan Kota.

\subsubsection{Sirkulasi}

Berkaitan dengan aksesibilitas jalan menuju ruang terbuka hijau publik, jenis perkerasan jalan, dan lebar jalan. Berikut Tabel 3 mengenai kategori RTHP Kota Yogyakarta berdasarkan variable sirkulasi.

Tabel 3. Kategori RTHP Kota Yogyakarta berdasarkan Variabel Sirkulasi

\begin{tabular}{|c|c|c|c|}
\hline No & Kategori & RTHP & Karakteristik \\
\hline 1 & $\mathrm{~A}$ & $\begin{array}{l}\text { Kantil, Pringgokusuman, Sorosutan I, Tahunan, Tegal Panggung, } \\
\text { Kadipaten, Brontokusuman III, Giwangan I, Giwangan II, Gedong } \\
\text { Kiwo, Purbayan, Flamboyan, Jatimulyo, Gajahwong Edu Park, } \\
\text { Golo, Purwokinanti, Klitren, Kehati, Sorosutan II, } \\
\text { Brontokusuman II, Demangan, Bakung, Rejowinangun, Taman } \\
\text { Wifi Gajahwong, Keparakan, Kelurahan Baciro, Tegalrejo, } \\
\text { Brontokusuman I, dan Bumijo, }\end{array}$ & $\begin{array}{l}\text { Dapat dilalui kendaraan bermotor } \\
\text { - Perkerasan aspal } \\
\text { Tidak ada lahan parkir }\end{array}$ \\
\hline 2 & B & $\begin{array}{l}\text { Pandeyan, Wirogunan I, Karangwaru, Muja Muju Timoho, } \\
\text { Notoprajan, Ngupasan, Sosromenduran, Wirogunan II, } \\
\text { Prenggan, Mantrijeron, Semaki, Prawirodirjan, Bener, Muja } \\
\text { Muju Janturan dan Kadipaten Kulon }\end{array}$ & $\begin{array}{l}\text { - Dapat dilalui motor dan pejalan kaki } \\
\text { - Tidak ada lahan parkir }\end{array}$ \\
\hline 3 & $\mathrm{C}$ & Terban, Genung Ketur, dan Cokrodiningratan & $\begin{array}{l}\text { - Dapat dilalui pejalan kaki } \\
\text { - Perkerasan rabat beton } \\
\text { - Tidak ada lahan parkir }\end{array}$ \\
\hline
\end{tabular}

Kategori RTHP di Kota Yogyakarta ditinjau dari variabel sirkulasi dibagi menjadi 3 (tiga) kategori, yaitu kategori A, B dan C (Gambar 2). Kategori yang paling dominan yaitu sebanyak 29 RTHP atau 61,7\% adalah kategori A dengan karakteristik sirkulasi dapat dilalui kendaraan bermotor baik roda 2 (dua) maupun 4 (empat), perkerasan jalan berupa aspal dan tidak ada lahan parkir di dalam RTHP. Persentase dominan ke-dua adalah kategori B sebanyak 15 RTHP atau 31,9\% dengan karaketristik sirkulasi dapat dilalui oleh sepeda motor dan pejalan kaki, perkerasan jalan aspal dan tidak memiliki lahan parkir. Sedangkan persentase terendah adalah kategori C sebanyak 3 RTHP atau 6,38\%, dengan karakteristik sirkulasi hanya dapat dilalui oleh pejalan kaki, perkerasan jalan dari rabat beton dan tidak terdapat lahan parkir di RTHP.

Menurut teori, disebutkan bahwa sirkulasi berkaitan dengan aksesibilitas jalan menuju ruang terbuka hijau publik, jenis perkerasan jalan, dan lebar jalan. Sehingga menurut penjabaran diatas, semakin mudah diakses akan semakin nyaman RTHP tersebut. Berdasarkan perbedaan karakteristik RTHP, maka yang memiliki aspek kenyamanan tertinggi adalah kategori A, yaitu dapat dilalui kendaraan bermotor dan dengan perkerasan aspal

Berdasarkan penjabaran hasil diatas dapat diperoleh kesimpulan bahwa seluruh RTHP di Kota Yogyakarta tidak memiliki lahan parkir, baik di dalam Kawasan RTHP maupun di luar RTHP. Penyediaan 
lahan parkir biasanya di depan rumah warga atau di depan RTHP (jenis parkir on street). Bagi RTHP yang hanya bisa dilalui oleh pejalan kaki, pengunjung/masyarakat harus menuntun motornya atau parkir di rumah warga yang menyediakan jasa penitipan motor. Mengingat bahwa Kota Yogyakarta memiliki lahan kosong yang terbatas, maka pemerintah menyediakan RTHP skala lingkungan RT dan RW untuk mencukupi kebutuhan 20\% akan RTHP perKotaan. Sehingga dapat dimaklumi dengan keberadaan RTHP yang hanya dapat dilalui oleh pejalan kaki, ini membuktikan bahwa pemerintah Kota memanfaatkan lahan-lahan kosong yang berada di tengah-tengah permukiman, bukan hanya perumahan/permukiman berkepadatan rendah namun juga di permukiman berkepadatan tinggi. Karena hampir sebanyak 38,38\% RTHP hanya dapat diakses dengan motor atau berjalan kaki.

Keberadaan RTHP yang hanya dapat diakses oleh kendaraan bermotor dan pejalan kaki bukan menjadi masalah, karena sasaran dari pengguna RTHP ini adalah warga sekitar RTHP agar memperoleh kemudahan akses ruang publik untuk menunjang kenyamanan mereka dalam beraktivitas. Berikut peta persebaran kategori RTHP berdasarkan variabel sirkulasi.

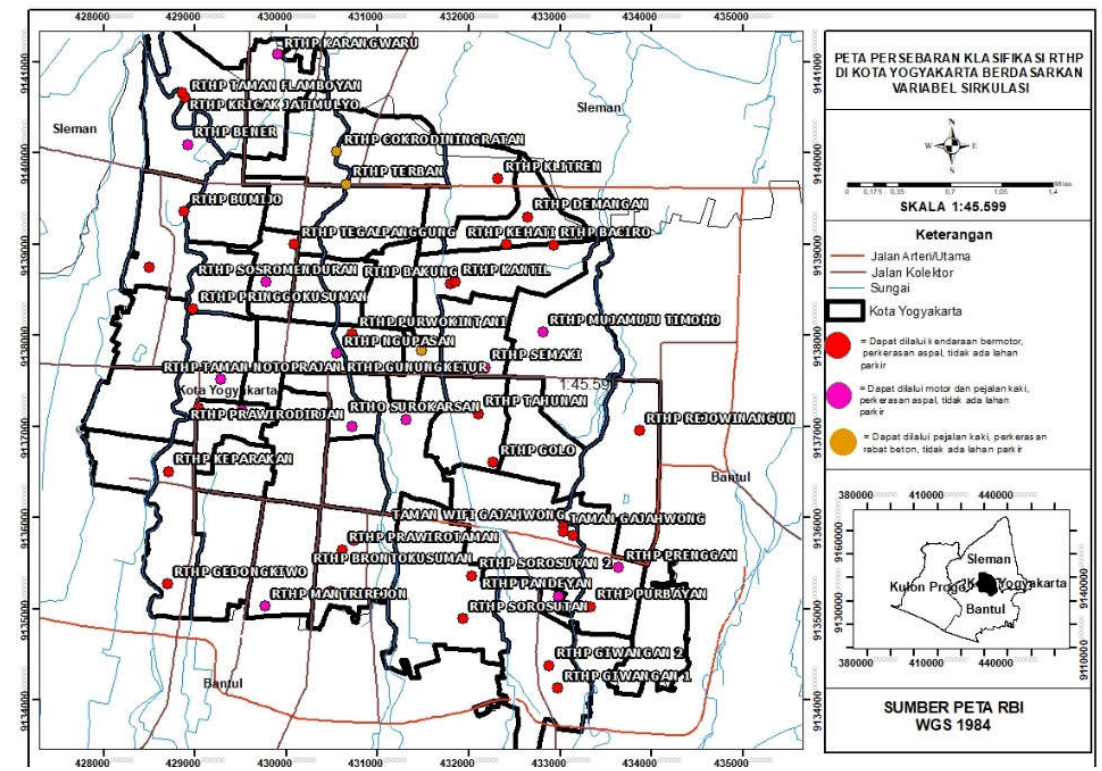

Gambar 2. Persebaran Kategori RTHP di Kota Yogyakarta berdasarkan Variabel Sirkulasi

\subsubsection{Kebersihan}

Berkaitan dengan seberapa banyak fasilitas kebersihan yang mendukung kenyamanan dan kondisi kebersihan diruang terbuka hijau publik tersebut. Berikut merupakan tabel kategori RTHP Variabel Kebersihan di Kota Yogyakarta.

Kategori RTHP di Kota Yogyakarta berdasarkan variabel kebersihan menunjukkan bahwa terdapat 9 kategori dengan kode A-I (Gambar 3). Karakteristik yang dipergunakan untuk kategori adalah tempat sampah, toilet dan tempat cuci tangan. Kategori yang paling dominan yaitu kode G dengan 18 RTHP atau $38,29 \%$ dengan karakteristik tempat sampah telah dibedakan jenisnya, tersedia toilet dengan kondisi bagus dan bersih serta tersedia tempat cuci tangan. Kategori G berada di RTHP Muja Muju Janturan, Semaki, Tegalrejo, Keparakan, Bakung, Demangan, Brontokusuman, Purwokinanti, Gajahwong Edu Park, Jatimulyo, Flamboyan, Purbayan, Karangwaru, Gedong Kiwo, Wirogunan I, Kadipaten, Pandeyan, dan Sorosutan I Sedangkan kategori terendah yaitu kategori $H$ dengan 2 RTHP atau 4,26\% dengan karakteristik tempat sampah dibedakan jenisnya, tidak ada toilet dan tidak ada tempat cuci tangan. Kategori ini terdapat pada RTHP Bumijo dan Cokrodiningratan.
Menurut teori, disebutkan bahwa kebersihan berkaitan dengan seberapa banyak fasilitas kebersihan yang mendukung kenyamanan dan kondisi kebersihan diruang terbuka hijau publik tersebut. Sehingga menurut penjabaran diatas, semakin banyak fasilitas maka akan semakin nyaman. Berdasarkan perbedaan karakteristik RTHP, maka yang memiliki aspek kenyamanan tertinggi adalah kategori G, yaitu tempat sampah dibedakan jenisnya, toilet dalam kondisi bagus dan bersih serta tersedia tempat cuci tangan.

Berdasarkan kondisi diatas dapat disimpulkan bahwa pemerintah Kota Yogyakarta telah cukup serius dalam menyediakan sarana kebersihan dan kesehatan, dengan ditemukannya 38,29\% RTHP dengan karakteristik tempat sampah telah dibedakan jenisnya, tersedia toilet dengan kondisi bagus dan bersih serta tersedia tempat cuci tangan. Keberadaan tempat cuci tangan juga dapat menjawab kondisi pandemi yang terjadi. Fasilitas kebersihan yang kurang adalah sebesar 10,63\% yaitu kategori C dengan rincian karakteristik tempat sampah tidak layak/tidak ada, tidak tersedia toilet dan tidak ada tempat cuci tangan. Kategori ini terdapat pada RTHP Tegal Panggung, Muja Muju Timoho, Notoprajan, Prawirodirjan dan Kadipaten Kulon. 
Tabel 4. Kategori RTHP Kota Yogyakarta berdasarkan Variabel Kebersihan

\begin{tabular}{|c|c|c|c|}
\hline No & Kategori & RTHP & Karakteristik \\
\hline 1 & A & $\begin{array}{l}\text { Kantil, Giwangan II, Golo, Terban, Taman Wifi Gajahwong, } \\
\text { Kelurahan Baciro, dan Taman Brontokusuman }\end{array}$ & $\begin{array}{l}\text { - Tempat sampah tidak layak/tidak ada } \\
\text { - Tidak tersedia toilet } \\
\text { - Tersedia tempat cuci tangan }\end{array}$ \\
\hline 2 & B & Kehati, Prenggan, dan Mantrijeron & $\begin{array}{l}\text { - Tempat sampah tidak layak/tidak ada } \\
\text { - Tersedia toilet bagus dan bersih } \\
\text { - Tersedia tempat cuci tangan }\end{array}$ \\
\hline 3 & $\mathrm{C}$ & $\begin{array}{l}\text { Tegal Panggung, Muja Muju Timoho, Notoprajan, Prawirodirjan } \\
\text { dan Kadipaten Kulon }\end{array}$ & $\begin{array}{l}\text { - Tempat sampah tidak layak/tidak ada, } \\
\text { - Tidak tersedia toilet } \\
\text { - Tidak tersedia tempat cuci tangan }\end{array}$ \\
\hline 4 & $\mathrm{D}$ & Sosromenduran, Rejowinangun, Gunung Ketur, dan Bener & $\begin{array}{l}\text { - Tempat sampah tidak layak/tidak ada } \\
\text { - Tersedia toilet bagus dan bersih } \\
\text { - Tidak ada tempat cuci tangan }\end{array}$ \\
\hline 5 & $\mathrm{E}$ & Pringgokusuman dan Tahunan & $\begin{array}{l}\text { - Tempat sampah tidak layak/tidak ada, } \\
\text { - Toilet kotor } \\
\text { - Tersedia tempat cuci tangan }\end{array}$ \\
\hline 6 & $\mathrm{~F}$ & Brontokusuman III, Giwangan I, dan Wirogunan II & $\begin{array}{l}\text { - Tempat sampah dibedakan jenisnya } \\
\text { - Tidak ada toilet } \\
\text { - Tersedia tempat cuci tangan }\end{array}$ \\
\hline 7 & G & $\begin{array}{l}\text { Muja Muju Janturan, Semaki, Tegalrejo, Keparakan, Bakung, } \\
\text { Demangan, Brontokusuman, Purwokinanti, Gajahwong Edu Park, } \\
\text { Jatimulyo, Flamboyan, Purbayan, Karangwaru, Gedong Kiwo, } \\
\text { Wirogunan I, Kadipaten, Pandeyan, dan Sorosutan I }\end{array}$ & $\begin{array}{l}\text { - Tempat sampah dibedakan jenisnya } \\
\text { - Tersedia toilet dengan kondisi bagus dan } \\
\text { bersih } \\
\text { - Tersedia tempat cuci tangan }\end{array}$ \\
\hline 8 & $\mathrm{H}$ & Bumijo dan Cokrodiningratan & $\begin{array}{l}\text { - Tempat sampah dibedakan jenisnya } \\
\text { - Tidak ada toilet } \\
\text { - Tidak ada tempat cuci tangan }\end{array}$ \\
\hline 9 & I & Ngupasan, Klitren, dan Sorosutan II & $\begin{array}{l}\text { - Tempat sampah dibedakan jenisnya } \\
\text { - Tersedia toilet bagus dan bersih } \\
\text { - Tiidak ada tempat cuci tangan }\end{array}$ \\
\hline
\end{tabular}

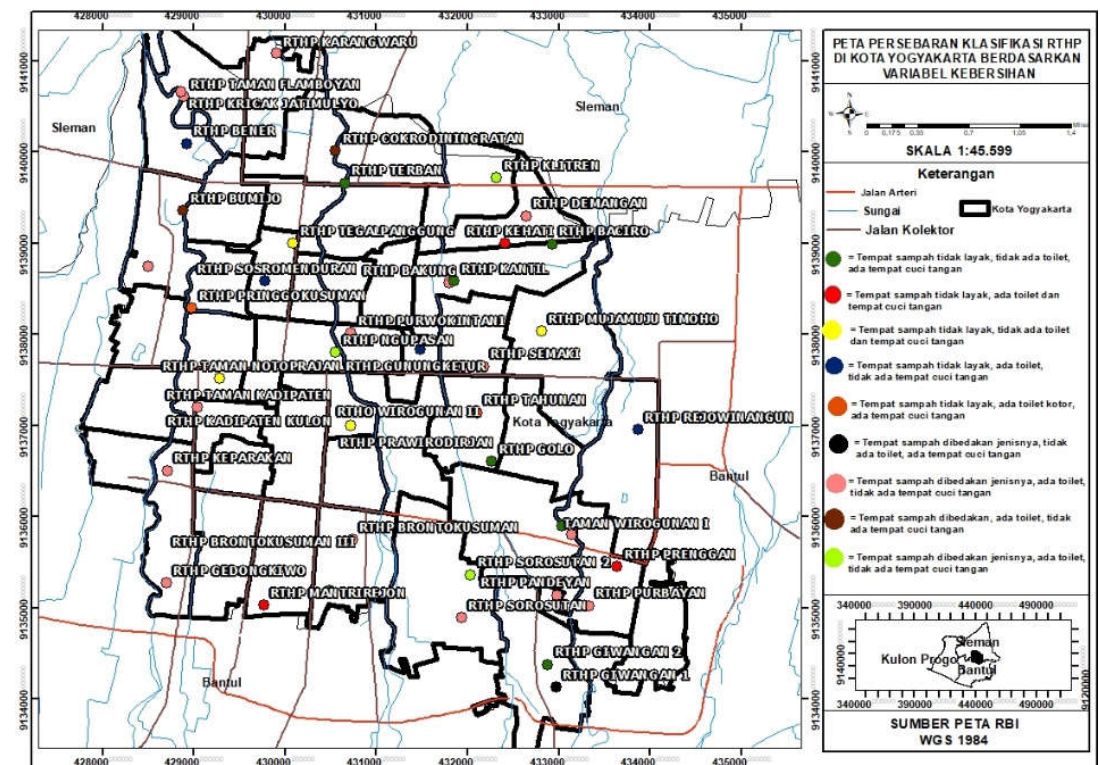

Gambar 3. Persebaran Kategori RTHP di Kota Yogyakarta berdasarkan Variabel Kebersihan

\subsubsection{Keamanan}

Variabel ini berkaitan dengan bagaimana kondisi keamanan di RTHP, apakah terdapat fasilitas keamanan dan personil yang menjaga kemanan. Baik di dalam RTHP maupun di luar RTHP. Tabel 5 menunjukkan kategori karakteristik keamanan di Kota Yogyakarta.

Kategori RTHP Kota Yogyakarta ditinjau dari variabel keamanan dibagi menjadi dua kategori (Gambar 4), yaitu kode A dan B. Kategori dominan yaitu kategori A berjumlah 40 RTHP atau sebesar $85,11 \%$ yang berada di RTHP Kantil, Pringgokusuman, Sorosutan I, Pandeyan, Tahunan, Tegal Panggung, Brontokusuman III, Wirogunan I,
Giwangan I, Giwangan II, Gedong Kiwo, Karangwaru, Flamboyan, Notoprajan, Ngupasan, Jatimulyo, Sosromenduran, Golo, Purwokinanti, Terban, Klitren, Kehati, Sorosutan II, Brontokusuman, Demangan, Bakung, Wirogunan II, Taman Wifi Gajahwong, Keparakan, Kelurahan Baciro, Tegalrejo, Taman Brontokusuman, Gunung Ketur, Mantrijeron, Semaki, Prawirodirjan, Bener, Muja Muju Janturan, Cokrodiningratan dan Kadipaten Kulon. Sedangkan kategori terendah/minoritas yaitu kategori B dengan jumlah 7 RTHP atau sebesar 14,89\% yang berada di RTHP Kadipaten, Purbayan, Muja Muju Timoho, Gajahwong Edu Park, Prenggan, Rejowinangun, dan Bumijo. 
Tabel 5. Kategori RTHP Kota Yogyakarta berdasarkan Variabel Keamanan

\begin{tabular}{|c|c|c|c|}
\hline No & Kategori & RTHP & Karakteristik \\
\hline 1 & $\mathrm{~A}$ & $\begin{array}{l}\text { Kantil, Pringgokusuman, Sorosutan I, Pandeyan, } \\
\text { Tahunan, Tegal Panggung, Brontokusuman III, } \\
\text { Wirogunan I, Giwangan I, Giwangan II, Gedong Kiwo, } \\
\text { Karangwaru, Flamboyan, Notoprajan, Ngupasan, } \\
\text { Jatimulyo, Sosromenduran, Golo, Purwokinanti, } \\
\text { Terban, Klitren, Kehati, Sorosutan II, Brontokusuman, } \\
\text { Demangan, Bakung, Wirogunan II, Taman Wifi } \\
\text { Gajahwong, Keparakan, Kelurahan Baciro, Tegalrejo, } \\
\text { Taman Brontokusuman, Gunung Ketur, Mantrijeron, } \\
\text { Semaki, Prawirodirjan, Bener, Muja Muju Janturan, } \\
\text { Cokrodiningratan dan Kadipaten Kulon }\end{array}$ & $\begin{array}{l}\text { - } \text { Terletak di dalam kampung, dekat dengan } \\
\text { - } \quad \text { Wermukiman warga } \\
\text { - } \quad \text { Kendaraan parkir di dalam dan luar RTHP }\end{array}$ \\
\hline 2 & B & $\begin{array}{l}\text { Kadipaten, Purbayan, Muja Muju Timoho, Gajahwong } \\
\text { Edu Park, Prenggan, Rejowinangun, dan Bumijo }\end{array}$ & $\begin{array}{l}\text { - Terletak di dalam komplek perumahan, } \\
\text { dekat dengan permukiman warga } \\
\text { - Terdapat security komplek yang ikut } \\
\text { menjaga keamanan RTHP } \\
\text { - } \quad \text { Kendaraan parkir di dalam dan luar RTHP }\end{array}$ \\
\hline
\end{tabular}

Menurut teori, disebutkan bahwa keamanan berkaitan dengan terdapatnya fasilitas keamanan dan personil yang menjaga kemanan, baik di dalam RTHP maupun di luar RTHP. Sehingga menurut penjabaran diatas, tersedia fasilitas keamanan dan personil yang menjaga keamanan maka RTHP akan semakin nyaman. Berdasarkan perbedaan karakteristik RTHP, maka kategori A lebih nyaman dari segi keamanan, karena terletak dekat dengan permukiman warga dan keikutsertaan warga untuk menjaga keamanan RTHP.

Kategori RTHP dibedakan menurut aspek lokasi RTHP, siapa yang menjaga keamanan RTHP apakah warga sekitar atau penjaga keamanan resmi/security, serta keberadaan parkir kendaraan. Berdasarkan perbedaan karakteristik diperoleh hasil bahwa RTHP yang terletak pada komplek perumahan akan memiliki less belonging, karena kurangnya partisipasi masyarakat dalam memanfaatkan RTHP. Bahkan ada beberapa RTHP yang terletak di perkampungan menjadikan pendopo/gazebo di dalam RTHP sebagai pos jaga untuk titik berkumpul saat siskamling (ronda malam). Kekurangan dua kategori RTHP tersebut adalah sama-sama belum memiliki tempat parkir baik di dalam maupun di luar RTHP. Sehingga dari segi estetika kurang bagus apabila kendaraan diletakkan sembarangan serta rawan pencurian kendaraan. Selain itu juga, karena letaknya yang berdekatan dengan rumah warga, banyak warga yang memarkir kendaraannya di dalam kawasan RTHP. Hendaknya pemerintah dapat menyediakan lahan parkir dan bisa dilengkapi dengan parkir untuk sepeda karena banyak anak kecil yang menuju ke RTHP menggunakan sepeda.

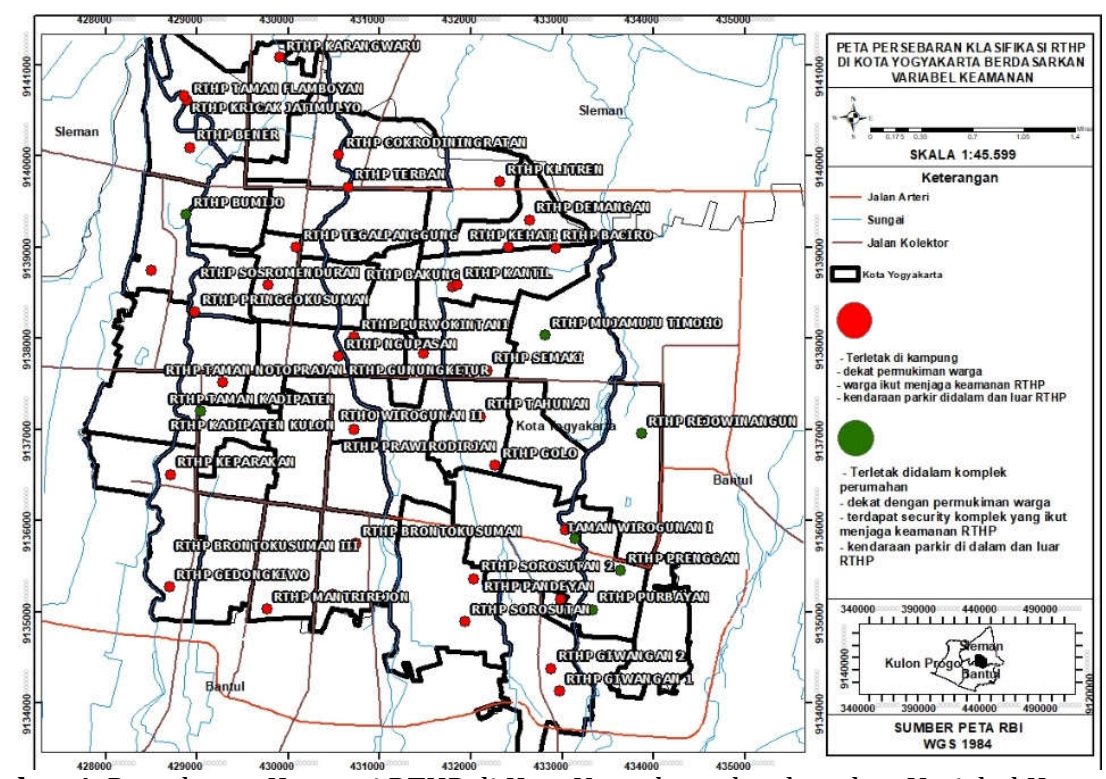

Gambar 4. Persebaran Kategori RTHP di Kota Yogyakarta berdasarkan Variabel Keamanan

\subsubsection{Keindahan}

Variabel ini berkaitan dengan unsur estetika yang ada diruang terbuka hijau publik tersebut, bagaimana memberikan suasana yang indah dipandang secara visual, memiliki point of interest, kerapian penataan tanaman dan fasilitas, serta adanya permainan warna.
Tabel berikut menunjukkan kategori karakteristik keindahan pada RTHP di Kota Yogyakarta.

Kategori RTHP Kota Yogyakarta ditinjau dari variabel keindahan terbagi menjadi 12 kategori, dengan kode A-L (Gambar 5). Pengelompokkan berdasarkan aspek ornamen tambahan, jenis 
perkerasan, warna cat dan vegetasi. Kategori dominan adalah kategori $G$ dengan jumlah 13 RTHP atau 27,66\% yang berada pada RTHP Pringgokusuman, Wirogunan I, Giwangan I, Notorprajan, Golo, Terban, Klitren, Kehati, Rejowinangun, Kelurahan Baciro, Prawirodirjan, Cokrodiningratan, dan Kadipaten Kulon. Karakteristik kategori ini adalah tidak memiliki ornamen tambahan, jenis perkerasan paving/semen dan tanah, warna telah memudar, dan vegetasi sedikit dan hanya terletak di pinggir RTHP. Sedangkan kategori RTHP yang memiliki kesamaan karateristik paling sedikit adalah kategori A dan F dengan 1 RTHP atau sebesar 2,13\%. Kategori A terdapat di RTHP Muja Muju Janturan dengan karakteristik memiliki ornamen tambahan, jenis perkerasan paving/semen dan tanah, warna telah memudar, dan vegetasi sedikit dan hanya terletak di pinggir RTHP. Selanjutnya, untuk kategori F terdapat di RTHP Kantil dengan karakteristik tidak memiliki ornamen tambahan, jenis perkerasan paving/semen dan tanah, warna telah memudar, dan vegetasi banyak serta terletak menyebar di seluruh RTHP.

Tabel 6. Kategori RTHP Kota Yogyakarta berdasarkan Variabel Keindahan

\begin{tabular}{|c|c|c|c|}
\hline No & Kategori & RTHP & Karakteristik \\
\hline 1 & A & Muja Muju Janturan & $\begin{array}{l}\text { - Memiliki ornamen tambahan } \\
\text { - Jenis perkerasan paving/semen dan tanah } \\
\text { - Warna telah memudar } \\
\text { - Vegetasi sedikit dan hanya terletak di pinggir RTHP }\end{array}$ \\
\hline 2 & B & Wirogunan II, Giwangan II, dan Gedong Kiwo, & $\begin{array}{l}\text { - Jenis perkerasan paving/semen dan rumput } \\
\text { - Warna cerah, tidak memudar } \\
\text { - Megetasi sedikit dan hanya terletak di pinggir RTHP } \\
\text { Memiliki ornamen tambahan }\end{array}$ \\
\hline 3 & $\mathrm{C}$ & Taman Wifi Gajahwong dan Tegalrejo & $\begin{array}{l}\text { - Jenis perkerasan paving/semen dan tanah } \\
\text { - Warna telah memudar } \\
\text { - Vegetasi sedikit dan hanya terletak di pinggir RTHP } \\
\text { Memiliki ornamen tambahan }\end{array}$ \\
\hline 4 & D & $\begin{array}{l}\text { Sorosutan I, Kadipaten, Flamboyan, Gajahwong Edu } \\
\text { Park, Sorosutan II, Bakung, Gunung Ketur dan Semaki }\end{array}$ & $\begin{array}{l}\text { - Jenis perkerasan paving/semen dan rumput } \\
\text { - Warna cerah, tidak memudar } \\
\text { RTHP }\end{array}$ \\
\hline 5 & E & Brontokusuman III, Purwokinanti, Brontokusuman & $\begin{array}{l}\text { - Memiliki ornamen tambahan } \\
\text { - Jenis perkerasan paving/semen dan rumput } \\
\text { - Warna cerah, tidak memudar } \\
\text { - Vegetasi sedikit dan hanya terletak di pinggir RTHP } \\
\text { - Tidak memiliki ornamen tambahan }\end{array}$ \\
\hline 6 & $\mathrm{~F}$ & Kantil & $\begin{array}{l}\text { - Jenis perkerasan paving/semen dan tanah } \\
\text { - Warna telah memudar } \\
\text { - Vegetasi banyak dan terletak menyebar di seluruh } \\
\text { RTHP }\end{array}$ \\
\hline 7 & G & $\begin{array}{l}\text { Pringgokusuman, Wirogunan I, Giwangan I, } \\
\text { Notorprajan, Golo, Terban, Klitren, Kehati, } \\
\text { Rejowinangun, Kelurahan Baciro, Prawirodirjan, } \\
\text { Cokrodiningratan, dan Kadipaten Kulon }\end{array}$ & $\begin{array}{l}\text { - Tidak memiliki ornamen tambahan } \\
\text { - Jenis perkerasan paving/semen dan tanah } \\
\text { - Warna telah memudar } \\
\text { - Vegetasi sedikit dan hanya terletak di pinggir RTHP } \\
\text { - Tidak memiliki ornamen tambahan }\end{array}$ \\
\hline 8 & $\mathrm{H}$ & Sosromenduran dan Taman Brontokusuman, & $\begin{array}{l}\text { - Jenis perkerasan paving/semen dan tanah } \\
\text { - Warna cerah, tidak memudar } \\
\text { RTHP }\end{array}$ \\
\hline 9 & I & Ngupasan, Demangan, Keparakan, dan Bumijo, & $\begin{array}{l}\text { - Tidak memiliki ornamen tambahan } \\
\text { - Jenis perkerasan paving/semen dan tanah } \\
\text { - Warna cerah, tidak memudar } \\
\text { - Vegetasi sedikit dan hanya terletak di pinggir RTHP } \\
\text { - Tidak memiliki ornamen tambahan }\end{array}$ \\
\hline 10 & $\mathrm{~J}$ & Tahunan, Prenggan, Mantrijeron, dan Bener & $\begin{array}{l}\text { - Jenis perkerasan paving/semen dan rumput } \\
\text { - Warna telah memudar } \\
\text { - Vegetasi sedikit dan hanya terletak di pinggir RTHP } \\
\text { - Jenis memiliki ornamen tambahan } \\
\text { - Jenis perasan paving/semen dan rumput }\end{array}$ \\
\hline 11 & $\mathrm{~K}$ & Tegal Panggung dan Purbayan, & $\begin{array}{l}\text { - Warna cerah, tidak memudar } \\
\text { - Vegetasi banyak dan terletak menyebar di seluruh } \\
\text { RTHP }\end{array}$ \\
\hline 12 & $\mathrm{~L}$ & Pandeyan, Karangwaru, Purbayan, dan Jatimulyo, & $\begin{array}{l}\text { - Tidak memiliki ornamen tambahan } \\
\text { - Jenis perkerasan paving/semen dan rumput } \\
\text { - Warna cerah, tidak memudar } \\
\text { - Vegetasi sedikit dan hanya terletak di pinggir RTHP }\end{array}$ \\
\hline
\end{tabular}

Menurut teori, disebutkan keindahan berkaitan dengan kemampuan memberikan suasana yang indah dipandang secara visual, memiliki point of interest, kerapian penataan tanaman dan fasilitas, serta adanya permainan warna. Sehingga kategori yang nyaman menurut indikator tersebut adalah kategori $\mathrm{D}$, dengan karakteristik memiliki ornamen tambahan, jenis perkerasan paving/semen dan rumput, memiliki 
warna cerah dan tidak memudar, serta memiliki banyak vegetasi yang menyebar di seluruh RTHP

Keindahan RTHP berkaitan dengan unsur estetika dan memiliki point of interest, sehingga salah satunya adalah ketersediaan ornamen tambahan yang dapat menarik masyarakat/pengunjung untuk menikmati suasana RTHP. Ornamen tersebut dapat berupa patung dan kolam ikan yang berada di Gajah Wong Edu Park. RTHP yang memiliki aspek keindahan secara keseluruhan adalah kategori D, yaitu RTHP Sorosutan I, Kadipaten, Flamboyan, Gajahwong Edu
Park, Sorosutan II, Bakung, Gunung Ketur dan Semaki. Karakteristik RTHP ini adalah memiliki ornamen tambahan, jenis perkerasan paving/semen dan rumput, warna cerah, tidak memudar, dan vegetasi banyak serta terletak menyebar di seluruh RTHP. Dengan terpenuhinya seluruh kriteria tersebut, maka diharapkan masyarakat/pengunjung akan semakin betah untuk memaksimalkan fungsi RTHP. Gambar 5 menunjukkan peta persebaran kategori RTHP berdasarkan variabel keindahan.

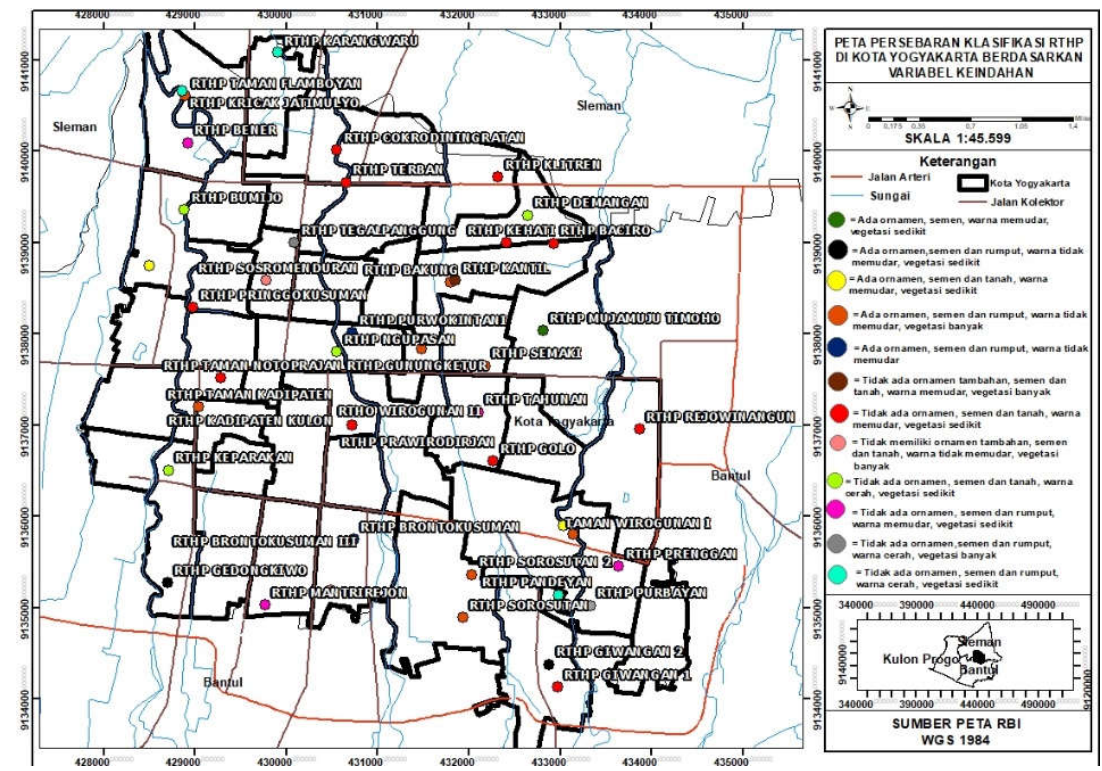

Gambar 5. Persebaran Kategori RTHP di Kota Yogyakarta berdasarkan Variabel Keindahan

\subsubsection{Bentuk}

Variabel ini berkaitan dengan penggunaan atau fungsi RTHP. Dengan asumsi bentuk yang cukup dan sesuai dapat menampung semua aktivitas masyarakat sekitar di RTHP. Menurut SNI kebutuhan luasan RTH Perkotaan dirancang dengan luasan 0,3-1 $\mathrm{m}^{2} /$ jiwa. Tabel 7 menunjukkan kategori karakteristik bentuk RTHP di Kota Yogyakarta.

Kategori RTHP Kota Yogyakarta ditinjau dari variabel bentuk memiliki 6 kategori, dengan kode A-F (Gambar 6). Kategori dominan adalah kategori A dan B, yaitu berjumlah 18 RTHP atau sebesar 38,29\%. Kategori A terdapat pada RTHP Tahunan, Tegal Panggung, Brontokusuman III, Wirogunan I, Giwangan II, Karangwaru, Muja Muju Timoho, Terban, Sorosutan II, Brontokusuman, Demangan, Taman Wifi Gajahwong, Keparakan, Kelurahan Baciro, Taman Brontokusuman, Mantrijeron, Semaki, dan Bener. Sedangkan kategori B terdapat pada RTHP Pringgokusuman, Sorosutan I, Pandeyan, Kadipaten, Gedong Kiwo, Purbayan, Notoprajan, Ngupasan, Sosromenduran, Golo, Purwokinanti, Wirogunan II, Prenggan, Prawirodirjan, Muja Muju Janturan, Cokrodiningratan, dan Kadipaten Kulon. Karakteristik untuk kategori A adalah memiliki luas 100-500 m² dan dapat menampung 1-2 dua aktivitas. Sedangkan karakteristik kategori B adalah memiliki luas 100-500 $\mathrm{m} 2$ dan dapat menampung $>2$ (dua) aktivitas.
Menurut teori, disebutkan variabel bentuk berkaitan dengan penggunaan atau fungsi RTHP. Sehingga kategori RTHP yang memberikan kenyamanan Kota menurut indikator tersebut adalah kategori E, dengan karakteristik memiliki memiliki luas $>1000 \mathrm{~m}^{2}$ dan dapat menampung 1-2 aktivitas.

Kategori dengan kesamaan karakteristik terendah adalah kategori $\mathrm{C}$ dan E berjumlah 1 RTHP atau 0,12\%. Kategori C berada di RTHP Rejowinangun dengan karakteristik memiliki luas 501-1000 m2 dan dapat menampung 1-2 dua aktivitas. Kategori E berada di RTHP Giwangan I dengan karakteristik memiliki luas $>1000 \mathrm{~m}^{2}$ dan dapat menampung 1-2 aktivitas. Variabel bentuk berkaitan dengan penggunaan atau fungsi RTHP, dengan asumsi bentuk yang cukup dan sesuai dapat menampung semua aktivitas masyarakat sekitar di RTHP. Menurut SNI kebutuhan luasan RTH PerKotaan dirancang dengan luasan 0,3-1 $\mathrm{m}^{2} /$ jiwa. Ketersediaan RTHP di Yogyakarta dari variabel bentuk telah sesuai dengan kebutuhan masyarakat, karena masyarakat dapat melakukan 1-2 bahkan lebih aktivitas di RTHP. Aktivitas tersebut berupa olahraga (tersedia lapangan voli, badminton, basket bahkan jogging track), bermain (tersedia wahana permainan anak), duduk santai/beristirahat (gazebo, tempat duduk taman) maupun melakukan kegiatan kesenian/koordinasi (tersedia pendopo). Kondisi tersebut menunjukkan bahwa ketersediaan RTHP di Kota Yogyakarta bukan 
hanya berfungsi sebagai preservasi lingkungan hidup namun juga menjadi sebuah ekosistem publik yang dapat dipergunakan masyarakat untuk bersosialisasi, menjaga kesehatan dan release stress. Gambar 6 menunjukkan peta persebaran kategori RTHP berdasarkan variabel keindahan.

Tabel 7. Kategori RTHP Kota Yogyakarta berdasarkan Variabel Bentuk

\begin{tabular}{|c|c|c|c|}
\hline No & Kategori & RTHP & Karakteristik \\
\hline 1 & A & $\begin{array}{l}\text { Tahunan, Tegal Panggung, Brontokusuman III, Wirogunan I, Giwangan II, } \\
\text { Karangwaru, Muja Muju Timoho, Terban, Sorosutan II, Brontokusuman, } \\
\text { Demangan, Taman Wifi Gajahwong, Keparakan, Kelurahan Baciro, Taman } \\
\text { Brontokusuman, Mantrijeron, Semaki, dan Bener }\end{array}$ & $\begin{array}{l}\text { - Memiliki luas } 100-500 \mathrm{~m}^{2} \\
\text { - Dapat menampung } 1-2 \text { dua } \\
\text { aktivitas }\end{array}$ \\
\hline 2 & B & $\begin{array}{l}\text { Pringgokusuman, Sorosutan I, Pandeyan, Kadipaten, Gedong Kiwo, } \\
\text { Purbayan, Notoprajan, Ngupasan, Sosromenduran, Golo, Purwokinant, } \\
\text { Wirogunan II, Prenggan, Prawirodirjan, Muja Muju Janturan, } \\
\text { Cokrodiningratan, dan Kadipaten Kulon }\end{array}$ & $\begin{array}{l}\text { - Memiliki luas } 100-500 \mathrm{~m}^{2} \\
\text { aktivitas }\end{array}$ \\
\hline 3 & $\mathrm{C}$ & Rejowinangun & $\begin{array}{l}\text { - Memiliki luas 501-1000 } \mathrm{m}^{2} \\
\text { - Dapat menampung } 1-2 \text { dua } \\
\text { aktivitas } \\
\text { - Memiliki luas } 501-1000 \mathrm{~m}^{2}\end{array}$ \\
\hline 4 & $\mathrm{D}$ & Flamboyan, Klitren, Bakung, Gunung Ketur, dan Bumijo & $\begin{array}{l}\text { - Dapat menampung > } 2 \text { (dua) } \\
\text { aktivitas }\end{array}$ \\
\hline 5 & E & Giwangan I & $\begin{array}{l}\text { - Memiliki luas }>1000 \mathrm{~m}^{2} \\
\text { - Dapat menampung } 1-2 \text { aktivitas } \\
\text { - Memiliki luas }>1000 \mathrm{~m}^{2}\end{array}$ \\
\hline 6 & $\mathrm{~F}$ & Kantil, Jatimulyo, Gajahwong Edu Park, dan Tegalrejo & $\begin{array}{l}\text { - Dapat menampung > } 2 \text { (dua) } \\
\text { aktivitas }\end{array}$ \\
\hline
\end{tabular}

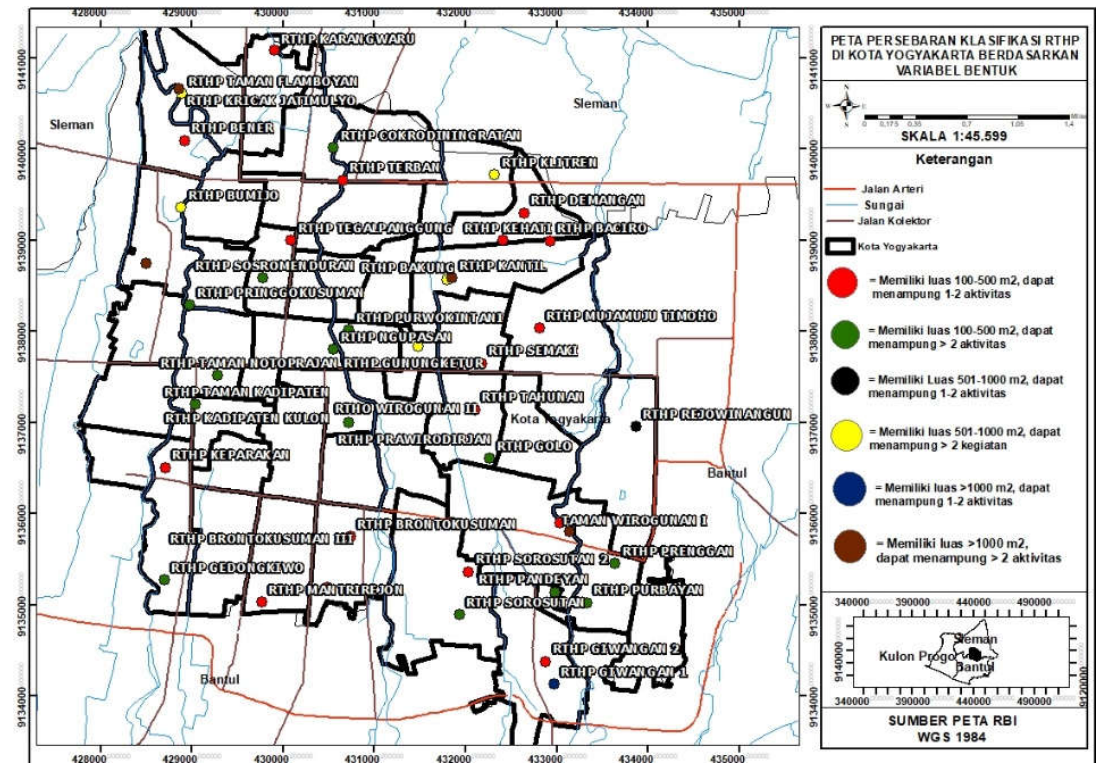

Gambar 6. Persebaran Kategori RTHP di Kota Yogyakarta berdasarkan Variabel Bentuk

\subsubsection{Kebisingan}

Variabel ini berkaitan dengan fungsi RTHP sebagai sumber bunyi bagi lingkungan sekitarnya maupun RTHP dapat berfungsi sebagai barrier bunyi dari lingkungan sekitar apabila berada di dalam RTHP. Tabel 8 menunjukkan kategori karakteristik kebisingan RTHP di Kota Yogyakarta.

Kategori RTHP di Kota Yogyakarta berdasarkan variabel kebisingan memiliki 4 kategori, dengan kode A-D (Gambar 7). Kategori dominan adalah kategori D berjumlah 14 RTHP atau sebesar 29,7\% yang berada di RTHP Kantil, Tegal Panggung, Kadipaten, Brontokusuman III, Golo, Purwokinanti, Klitren, Kehati, Brontokusuman, Demangan, Rejowinangun, Taman Wifi Gajahwong, Keparakan, dan Bumijo. Karakteristik kategori ini adalah dikelilingi oleh tanaman hias/ keberadaan pohon tinggi jarang, dan dekat dengan rel kereta api dan/ atau jalan lokal. Sedangkan RTHP yang memiliki kesamaan karakteristik tersendah adalah kategori B berjumlah 9 RTHP atau sebesar 19,15\%. Karakteristik kategori ini adalah dikelilingi oleh pohon-pohon tinggi dan dekat dengan rel kereta api dan/ atau jalan lokal.

Menurut teori, disebutkan variabel kebisingan berkaitan fungsi RTHP sebagai sumber bunyi bagi lingkungan sekitarnya maupun RTHP dapat berfungsi sebagai barrier bunyi dari lingkungan sekitar apabila berada di dalam RTHP. Sehingga kategori RTHP yang memberikan kenyamanan Kota menurut variabel kebisingan adalah kategori A, karena memiliki pohon tinggi sebagai barier bunyi, meskipun letaknya dekat dengan permukiman warga. 
Tabel 8. Kategori RTHP Kota Yogyakarta berdasarkan Variabel Kebisingan

\begin{tabular}{|c|c|c|c|}
\hline No & Kategori & "RTHP & Karakteristik \\
\hline 1 & A & $\begin{array}{l}\text { Sorosutan I, Pandeyan, Gedong Kiwo, Muja Muju Timoho, } \\
\text { Flamboyan, Sosromenduran, Prenggan, Gunung Ketur, } \\
\text { Manjtrijeron, Prawirodirjan, Bener dan Cokrodiningratan }\end{array}$ & $\begin{array}{l}\text { - Dikelilingi oleh pohon-pohon tinggi } \\
\text { - Berada di tengah-tengah permukiman warga } \\
\text { dan/ atau dekat dengan jalan lingkungan }\end{array}$ \\
\hline 2 & B & $\begin{array}{l}\text { Giwangan I, Giwangan II, Purbayan, Gajahwong Edu Park, } \\
\text { Sorosutan II, Bakung, Kelurahan Baciro, Tegalrejo, dan Taman } \\
\text { Brontokusuman }\end{array}$ & $\begin{array}{l}\text { - Dikelilingi oleh pohon-pohon tinggi } \\
\text { - Dekat dengan rel kereta api dan/ atau jalan } \\
\text { lokal }\end{array}$ \\
\hline 3 & $\mathrm{C}$ & $\begin{array}{l}\text { Pringgokusuman, Tahunan, Wirogunan I, Karang Waru, } \\
\text { Notoprajan, Ngupasan, Jatimulyo, Terban, Wirogunan II, } \\
\text { Semaki, Muja Muju Janturan dan Kadipaten Kulon }\end{array}$ & $\begin{array}{l}\text { - Dikelilingi oleh tanaman hias/ keberadaan } \\
\text { pohon tinggi jarang } \\
\text { - Berada di tengah-tengah permukiman warga } \\
\text { dan/ atau jalan lingkungan }\end{array}$ \\
\hline 4 & D & $\begin{array}{l}\text { Kantil, Tegal Panggung, Kadipaten, Brontokusuman III, Golo, } \\
\text { Purwokinanti, Klitren, Kehati, Brontokusuman, Demangan, } \\
\text { Rejowinangun, Taman Wifi Gajahwong, Keparakan, dan Bumijo }\end{array}$ & $\begin{array}{l}\text { - Dikelilingi oleh tanaman hias/ keberadaan } \\
\text { pohon tinggi jarang } \\
\text { - Dekat dengan rel kereta api dan/ atau jalan } \\
\text { lokal }\end{array}$ \\
\hline
\end{tabular}

Kebisingan di sini memiliki arti bahwa RTHP berfungsi sebagai sumber bunyi bagi lingkungan sekitarnya maupun RTHP dapat berfungsi sebagai barrier bunyi dari lingkungan sekitar apabila berada di dalam RTHP. Berdasarkan definisi operasional tersebut maka dapat disimpulkan bahwa kondisi ideal untuk menghindari kebisingan RTHP adalah RTHP yang dikelilingi pohon tinggi, berfungsi sebagai barrier bunyi dan berada di daerah permukiman (tidak dekat dengan jalan raya atau rel kereta api) sehingga meminimalkan masuknya bunyi kedalam RTHP. Sedangkan RTHP yang menjadi sumber bunyi/kebisingan jarang ditemukan karena kondisi covid, sehingga masyarakat masih jarang berkunjung ke RTHP dalam jangka waktu lama. Gambar 7 menunjukkan peta persebaran kategori RTHP berdasarkan variabel kebisingan.

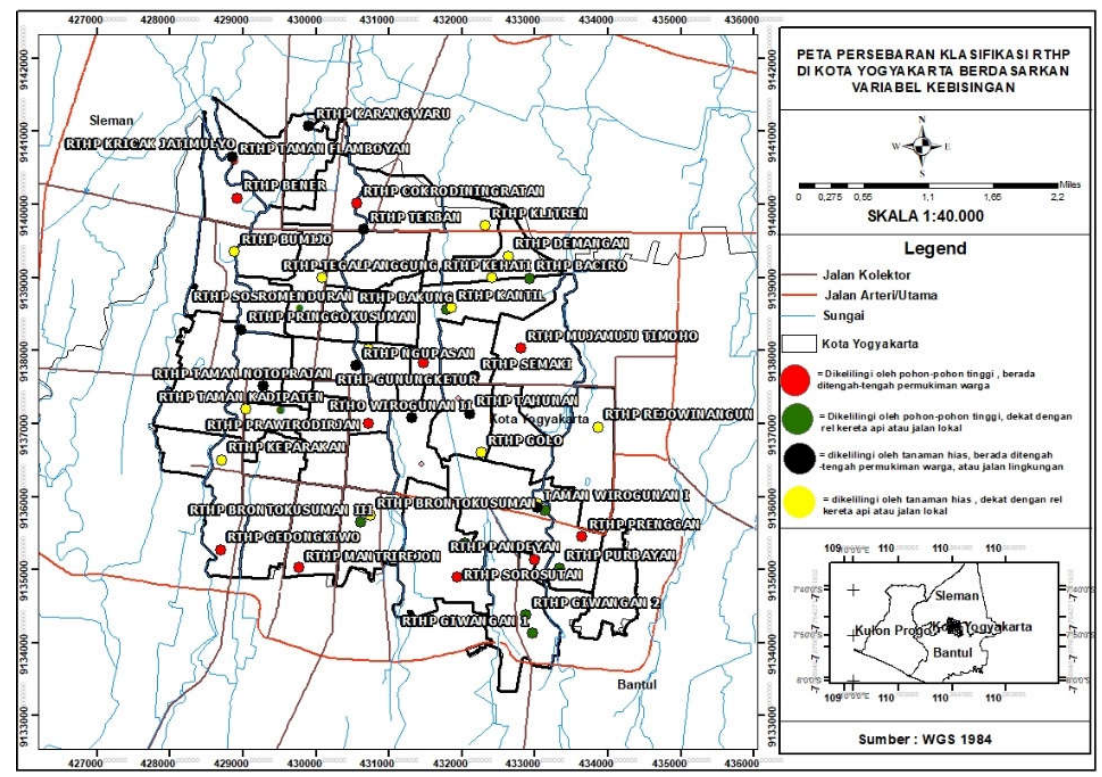

Gambar 7. Persebaran Kategori RTHP di Kota Yogyakarta berdasarkan Variabel Kebisingan

\subsubsection{Penerangan}

Variabel ini berkaitan dengan adanya penerangan buatan (lampu taman) yang berada di dalam maupun diluar RTHP. Selain itu dilihat dari cahaya matahari dapat secara langsung menyinari RTHP. Tabel 9 menunjukkan kategori karakteristik penerangan RTHP di Kota Yogyakarta.

Kategori RTHP di Kota Yogyakarta berdasarkan variabel penerangan memiliki 2 kategori, dengan kode A dan B (Gambar 8). Kategori dominan adalah kategori A dengan jumlah 45 RTHP atau sebesar 95,74\%, berada di RTHP Sorosutan I, Pandeyan, Gedong Kiwo, Muja Muju Timoho, Sosromenduran, Prenggan, Gunung Ketur, Manjtrijeron, Prawirodirjan, Bener Cokrodiningratan, Giwangan I, Giwangan II, Purbayan, Gajahwong Edu Park, Sorosutan II, Bakung,
Kelurahan Baciro, Tegalrejo, Taman Brontokusuman, Pringgokusuman, Tahunan, Wirogunan I, Karang Waru, Notoprajan, Ngupasan, Jatimulyo, Terban, Wirogunan II, Semaki, Muja Muju Janturan, Kadipaten Kulon, Kantil, Tegal Panggung, Brontokusuman III, Golo, Purwokinanti, Klitren, Kehati, Brontokusuman, Demangan, Rejowinangun, Taman Wifi Gajahwong, Keparakan, dan Bumijo. Karakteristik kategori ini adalah ketersediaan lampu di setiap sudut dan/atau mengelilingi RTHP.

Menurut teori, disebutkan variabel penerangan berkaitan dengan adanya penerangan buatan (lampu taman) yang berada di dalam maupun diluar RTHP, selain itu dilihat dari cahaya matahari dapat secara langsung menyinari RTHP. Sehingga kategori RTHP yang menunjang kenyamanan Kota menurut variabel 
penerangan adalah kategori A, karena memiliki lampu yang menyebar di seluruh RTHP.

Tabel 9. Kategori RTHP Kota Yogyakarta berdasarkan Variabel Penerangan

\begin{tabular}{|c|c|c|c|}
\hline No & Kategori & RTHP & Karakteristik \\
\hline 1 & A & $\begin{array}{l}\text { Sorosutan I, Pandeyan, Gedong Kiwo, Muja Muju Timoho, } \\
\text { Sosromenduran, Prenggan, Gunung Ketur, Manjtrijeron, Prawirodirjan, } \\
\text { Bener Cokrodiningratan, Giwangan I, Giwangan II, Purbayan, } \\
\text { Gajahwong Edu Park, Sorosutan II, Bakung, Kelurahan Baciro, } \\
\text { Tegalrejo, Taman Brontokusuman, Pringgokusuman, Tahunan, } \\
\text { Wirogunan I, Karang Waru, Notoprajan, Ngupasan, Jatimulyo, Terban, } \\
\text { Wirogunan II, Semaki, Muja Muju Janturan, Kadipaten Kulon, Kantil, } \\
\text { Tegal Panggung, Brontokusuman III, Golo, Purwokinanti, Klitren, } \\
\text { Kehati, Brontokusuman, Demangan, Rejowinangun, Taman Wifi } \\
\text { Gajahwong, Keparakan, dan Bumijo }\end{array}$ & $\begin{array}{l}\text { Lampu ada di setiap sudut dan/ atau } \\
\text { mengelilingi taman }\end{array}$ \\
\hline 2 & B & Kadipaten dan Flamboyan & $\begin{array}{l}\text { Lampu hanya ada di beberapa titik, tidak } \\
\text { tersebar merata }\end{array}$ \\
\hline
\end{tabular}

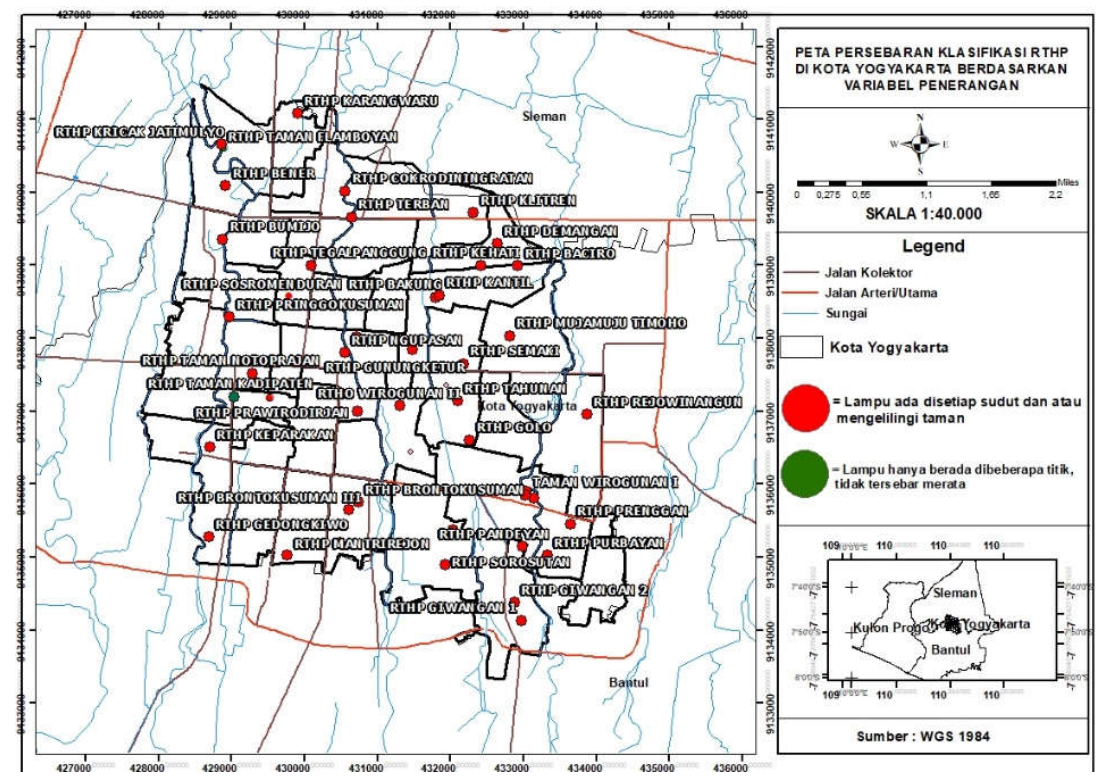

Gambar 8. Persebaran Kategori RTHP di Kota Yogyakarta berdasarkan Variabel Penerangan

Kategori dengan kesamaan karakteristik terendah adalah kategori B yaitu RTHP Kadipaten dan Flamboyan, hanya sebesar 4,26\%. Karakteristik RTHP ini adalah ketersediaan lampu taman yang hanya berada di beberapa titik, dan tidak tersebar merata. Adanya penerangan buatan (lampu taman) yang berada di dalam maupun diluar RTHP serta kemudahan cahaya matahari secara langsung menyinari RTHP merupakan kondisi ideal penerangan RTHP. Banyaknya RTHP yang telah memiliki penerangan baik $(95,74 \%)$ menunjukkan keseriusan pemerintah dalam menyediakan RTHP yang dapat digunakan masyarakat secara optimal (masyarakat dapat menggunakan sampai malam hari), meningkatkan estetika di malam hari dan juga meningkatkan keamanan masyarakat.

\section{Kesimpulan}

Kategori RTHP di Kota Yogyakarta dikelompokkan berdasarkan tujuh variabel, yaitu sirkulasi, kebersihan, keamanan, keindahan, bentuk, kebisingan dan penerangan. Variabel-variabel tersebut merupakan variabel untuk mengidentifikasi kenyamanan ruang terbuka. Asumsi yang ada adalah dengan ruang terbuka yang semakin nyaman, maka akan meningkatkan kenyamanan Kota. Pemerintah Kota Yogyakarta berencana memenuhi kebutuhan luasan RTH sebesar 30\% dari luasan Kota Yogyakarta dengan cara menyediakan RTHP yang terletak dekat dengan permukiman penduduk. Selain itu, pemerintah juga ingin meningkatkan aktivitas sosial/bersama masyarakat yang tinggal dekat dengan RTHP. Ditambah lagi dengan adanya RTHP yang dijadikan sebagai lokasi wisata, seperti pada RTHP Gajah Wong Edu Park. Namun, sayangnya masih banyak RTHP lainnya yang belum dibangun secara maksimal.

Kategori yang menunjang kenyamanan Kota adalah kelompok RTHP yang memiliki kualitas baik, sehingga membuat RTHP nyaman untuk dimanfaatkan oleh seluruh kelompok masyarakat. Untuk variabel sirkulasi kategori prioritas untuk meningkatkan kenyamanan adalah kategori A, variabel kebersihan adalah kategori G, variabel keamanan adalah kategori $A$, variabel keindahan adalah kategori $\mathrm{D}$, variabel bentuk adalah kategori $\mathrm{E}$, 
kebisingan adalah kategori D dan penerangan adalah kategori A.

Kategori yang memiliki nilai kesamaan karakteristik dominan adalah kategori yang hanya terdiri dari dua-tiga kode kategori. Seperti pada variabel keamanan, penerangan dan sirkulasi. Hal ini menunjukkan bahwa pemerintah memiliki konsep yang matang dan pemahaman mengenai aspek kenyamanan RTHP. Pada variabel keamanan hanya dibagi menjadi dua kategori, dimana variabel ini berkaitan erat dengan variabel sirkulasi RTHP. Untuk RTHP yang terletak di tengah perumahan dan ada penjaga keamanaan, maka sebagian besar karakteristik sirkulasinya cenderung dapat dilalui kendaraan bermotor dan perkerasan aspal. Sedangkan untuk RTHP yang terletak di dalam kampung dan warga ikut menjaga keamanan RTHP, maka karaketristik sirkulasinya cenderung dapat dilalui motor dan/atau pejalan kaki saja dengan perkerasan aspal atau rabat beton. Kategori yang memiliki sebaran karakteristik yang cukup luas (banyak memiliki perbedaan karakteristik) yaitu pada variabel keindahan dengan 12 kode kategori. Untuk perencanaan dan pembangunan RTHP selanjutnya, diharapkan pemerintah memiliki standar dalam mengidentifikasi variabel kenyamanan, sehiggga baik pengunjung maupun masyarakat sekitar dapat lebih nyaman beraktivitas di RTHP yang juga dapat menunjang kenyamanan Kota Yogyakarta.

\section{DAFTAR PUSTAKA}

Braharsyah, H. F., dan R, S. 2018. Kategori Ruang Terbuka Hijau Berbasis Objek Pada Citra Quickbird Untuk Mengetahui Akurasi Semantik, Di Denggung Kecamatan Sleman, Kabupaten Sleman Tahun 2017. Jurnal Bumi Indonesia, Vol. 6 No. 4. Hal. 1-10.
Dinas Lingkungan Hidup. 2020. Daftar Persebaran RTHP di Kota Yogyakarta 2019-2020.

IAP. 2017. Indonesia Most Liveable City Index.

Imansari, N., and Parfi, K. 2015. Provision of Urban Forests and Urban Parks as Public Green Open Space According to People's Preference in Downtown Area of Tangerang City. Ruang.

Noviyanti, I. K., dan Roychansyah, dan M. S. 2017. Kategori Ruang Terbuka Hijau Berbasis Objek Pada Citra Quickbird Untuk Mengetahui Akurasi Semantik, Di Denggung Kecamatan Sleman, Kabupaten Sleman Tahun 2017. Teknik Arsitektur Dan Perencanaan, Fakultas Teknik, Universitas Gadjah Mada. Hal. 1-10.

Olivia, O., dan A, A. D. 2018. Hubungan Antara Akses ke Ruang Terbuka Hijau dengan Kesehatan Mental di Surabaya. Jurnal Psikologis Klinis Dan Kesehatan Mental, Vol. 7. Hal. 84-96.

Pribadi, Wicaksono. 2020. Kiat Pemkot Yogyakarta Membuat Wilayahnya Makin Asri. Tempo.

Pusat Studi Gajah Mada. 2015. Pengelolaan RTH Kota Yogyakarta Kembali Dievaluasi.

Radar Jogja. 2008. Luas RTH Kota Jogja Jauh dari Target. Radar Jogja, 2018.

Sari, R. N. 2018. Ketersediaan Ruang Terbuka Hijau Berbasis Pelestarian Lingkungan di Kabupaten Sidoarjo. Jurnal Politik Dan Sosial Kemasyarakatan.

Siregar, D. C., Ardah, V. P., dan Ninggar, R. D. 2019. Identifikasi Kenyamanan Kota Tanjungpinang Berdasarkan Indeks Panas Humidex. Jurnal Ilmu Lingkungan, Vol. 17 No. 2. Hal. 316-322.

Syahadat, R. M., Putra, P. T., dan Pratiwi, M. D. 2017. Ruang Terbuka Hijau dan Permasalahan Kesehatan PerKotaan Studi Kasus di Provinsi DKI Jakarta. Jurnal Arsitektur Lansekap.

Wirastri, M. V., dan Pramudito, S. 2019. Identifikasi Aspek Kenyamanan Warga Terhadap Keberadaan Ruang Terbuka Publik di Kampung Gampingan Kota Yogyakarta. Jurnal Arsitektur Arcade.

V, S. K., Christine, P., and Hyun, K. 2002. Treating Open Space as an Urban Amenity. Resource and Energy Economics, Vol. 99 No. 3. Pages 107-129. 